\title{
THE EFFICIENCY OF HARMONISATION OF TURKISH BANKING REGULATION FOR RISK MANAGEMENT WITH THE EU*
}

\author{
İmre S. ERSOY**
}

\section{Abstract}

Turkey has adopted the Basel I international regulatory framework for risk management in accordance with the efforts to harmonize Turkish banking regulation with the EU. Turkey will also adopt Basel II, which will be finalised by mid-2004 and implemented by end-2006. Basel frameworks are designed by $G-10$ and are enforceable in G-10. EU makes minor adjustments to the Basel risk management frameworks and immediately initiates parallel directives. The Basel frameworks require minimum capital adequacy for credit, market and lately for operational risks of banks. Credit, market and operational risks are the major determinants of individual bank(s) problems in G-10 and in the EU. In Turkey, however, the systemic banking crises are due to institutional and also macroeconomic risks, mainly those of interest and exchange rate volatilities. The Basel framework increases the capital adequacy requirement of banks in Turkey but does not offer protection to the risks the banks in Turkey are exposed. The harmonization of banking regulation of Turkey with the $E U$ is important but the immunization of the system from crises will only be achieved with the adaptation of the risk management framework to Turkey, rather than precise adoption of the best practices.

* This article is the revised version of the Ph.D thesis titled "Harmonisation of the Turkish Banking Regulation to the EU, with special emphasis to Risk Management" submitted to the European Community Institute of University of Marmara in 2003.

** Dr., Marmara University, School of Banking and Insurarice. 


\section{Introduction}

The banking crises in the developing world like East Asian, Latin American conntries and Turkey are abundant and their frequency is increasing. Turkey had a systemic banking crisis in 1994 and a very costly one in 2000-2001. In 2002, Turkey adopted the amended Basle I framework and Turkish authorities already declared that Basel II would also be implemented in Turkey. However, Basel frameworks offer protection to credit, market and operational risks of banks as they are designed by G-10 as a remedy to the banking problems of G-10. The precise adoption of the Basel frameworks does not offer protection to major macroeconomic risk exposures of Turkish banks, namely those of interest rate and exchange rate volatilities.

In this context, in the first section, the risk exposures of banks to crises are elaborated for EU and Turkey. In section 2, risk management frameworks in the EU and Turkey are analysed and compared. In the third section, the problems Turkey encountered in the application of Basel I and possible problems to be encountered with the application of Basel II are examined. In the last section, proposals to increase the efficiency of risk management framework in Turkey are forwarded in terms of Basel Committee initiatives, responsibilities of Regulatory \& Supervisory Authority and responsibilities of banks in Turkey.

\section{The Banking. Risk Exposures in the EU and Turkey}

Banking is the business of managing risks. Banks all over the world are exposed to financial, operational, business and event risks and banking crises are due to bad management of one or a combination of these risks. Financial and operational risks are microeconomic, bank specific, risks. Business risks are institutional, system related, risks. Event risks are risks due to internal and / or external macroeconomic volatilities. The banking risk spectrum is illustrated in table 1.1 
Table 1.1: The Banking Risk Spectrum

\begin{tabular}{|l|l|l|l|}
\hline \multicolumn{1}{|c|}{ Financial Risks } & Operational Risks & Business Risks & Event Risks \\
\hline $\begin{array}{l}\text { Balance Sheet } \\
\text { Structure }\end{array}$ & Business Strategy Risk & Legal Risks & Political Risks \\
\hline $\begin{array}{l}\text { Income Statement } \\
\text { Structure }\end{array}$ & $\begin{array}{l}\text { Internal Sys. \& } \\
\text { Operational Risk }\end{array}$ & Policy Risks & Contagion Risk \\
\hline Capital Adequacy & Technology Risk & $\begin{array}{l}\text { Financial } \\
\text { Infrastructure }\end{array}$ & $\begin{array}{l}\text { Banking crisis } \\
\text { risk }\end{array}$ \\
\hline Credit Risk & Mismanagement\& fraud & $\begin{array}{l}\text { Systemic } \\
\text { (Country) Risk }\end{array}$ & $\begin{array}{l}\text { Other exogenous } \\
\text { risks }\end{array}$ \\
\hline Liquidity Risk & & & \\
\hline Interest Rate Risk & & & \\
\hline Market Risk & & & \\
\hline Currency Risk & & & \\
\hline Sour Ging & & & \\
\hline
\end{tabular}

Source: Greuning, H.and Bratanovic S. (2000). "Analysing Banking Risk: A

Framework for Assessing Corporate Governance and Financial Risk Management", pp.4, The World Bank, Washington D.C

The empirical studies show that the systemic banking crises in the developing countries are associated more with institutional risks and macroeconomic risks of GDP, interest rates, inflation rates, real exchange rates and external vulnerability. The individual bank failure(s) of the developed countries, however, are affected more by the microeconomic determinants associated with liquidity, market, and credit risks. ${ }^{1}$

\section{I.1 The Banking Risk Exposures in the EU}

In the EU, the banking problems are restricted to individual bank(s) problems and a EU-wide systemic risk is not evidenced. Gup (1998) asserts that almost $30 \%$ of failures (near failures) in the G-10 countries are due to problem loans, almost $20 \%$ due to real estate loans and $10 \%$ due to fraud like in the cases of BCCI and Credit Lyonnais. ${ }^{2}$ The Banking Crises list of G-10, as illustrated in table 1.2 , reveals that in the EU the major risk exposures are microeconomic risks, mainly those of credit, operational risks and market risk due to derivative exposures as in the case of Barings. 
Table 1.2: Banking Failures (Near Failures) in G-10 Countries

\begin{tabular}{|l|c|c|l|}
\hline \multicolumn{1}{|c|}{ Country } & Banks & Years & \multicolumn{1}{c|}{ Associated Risks } \\
\hline Belgium & 4 & 198019821997 & Poor management, liquidity, fraud \\
\hline France & 12 & $\begin{array}{c}198819891993 \\
1996\end{array}$ & Problem loans, Real Estate loans, fraud \\
\hline Germany & 2 & 19741983 & Loans, FX exposure \\
\hline Italy & 4 & 198219881996 & Problem loans, fraud \\
\hline Netherlands & 5 & 19811982 & $\begin{array}{l}\text { Real estate loans, Foreign Trade } \\
\text { Financing }\end{array}$ \\
\hline Sweden & 5 & 19911992 & Unknown \\
\hline Switzerland & 9 & $19801987-881991-$ & Excess risk, loan loss provisions \\
\hline U.K & 3 & $19841990-91$ & Loan quality/Loan losses/Fraud \\
\hline
\end{tabular}

Source: Derived from Benton E. Gup. (1998), "Bank Failures in the Major Trading Countries of the World: Causes and Remedies", pp.60-64, Quorum Books, London

\section{I.2 The Banking Risk Exposures in Turkey}

The banking crises in Turkey, the 1994 and particularly the 2000-2001 crises are systemic banking crisis. The funding of Public Sector Borrowing Requirement (PSBR) has been the most important duty of the banking system in Turkey since 1990s. Before the onset of the crisis, the liabilities of banks were being channelled to finance the government debt by creating crowding out as shown in table 1.3.

Table 1.3: Total Loans/Total Deposits in the EU and Turkish Banking Systems

\begin{tabular}{|c|c|c|c|c|c|}
\hline Countries & $\mathbf{1 9 9 7}$ & $\mathbf{1 9 9 8}$ & $\mathbf{1 9 9 9}$ & $\mathbf{2 0 0 0}$ & $\mathbf{2 0 0 1}$ \\
\hline Germany & 1,15 & 1,38 & 1,49 & 1,3 & 1,27 \\
\hline Austria & 1,11 & 0,81 & 1,02 & 0,79 & 0,8 \\
\hline Belgium & 0,9 & 1,06 & 1,03 & 1,05 & 0,97 \\
\hline Denmark & 0,86 & 0,87 & 0,92 & 1,02 & 1,03 \\
\hline Finland & 0,89 & 1,15 & 1,07 & 1,18 & 1,13 \\
\hline France & 1,2 & 1,3 & 1,33 & 1,35 & 1,23 \\
\hline Holland & 1,25 & 0,93 & 0,94 & 0,96 & 0,91 \\
\hline U.K & 1 & 0,97 & 0,99 & 1,02 & 0,99 \\
\hline Spain & 0,85 & 0,97 & 0,99 & 1,02 & 1,99 \\
\hline Sweden & 0,83 & 0,84 & 0,86 & 0,85 & 1,12 \\
\hline
\end{tabular}




\begin{tabular}{|c|c|c|c|c|c|} 
Italy & 1,31 & 1,37 & 1,46 & 1,69 & 1,72 \\
\hline Luxemburg & 0,49 & 0,51 & 0,6 & 0,57 & 0,64 \\
\hline Portugal & 0,72 & 0,85 & 0,99 & 1,13 & 1,2 \\
\hline Greece & 0,4 & 0,53 & 0,72 & 0,46 & 0,67 \\
\hline Ireland & 1,13 & 1,18 & 1,51 & 2,13 & 1,65 \\
\hline EU Average & $\mathbf{0 , 9 3}$ & $\mathbf{0 , 9 8}$ & $\mathbf{1 , 0 5}$ & $\mathbf{1 , 0 9}$ & $\mathbf{1 , 0 8}$ \\
\hline Turkey & $\mathbf{0 , 6 8}$ & $\mathbf{0 , 6}$ & $\mathbf{0 , 4 2}$ & $\mathbf{0 , 5 5}$ & $\mathbf{0 , 3 4}$ \\
\hline
\end{tabular}

Source: Eurostat (2001). Special Feature on Banking, European Federation Key Statistics

The banks' main job of funding PSBR created mismatches in the Balance Sheets (B/Ss) of banks due to the short maturities of deposits and long maturities of Capital Market Portfolios (CMPs). Figure 1.1 demonstrates the maturity structure of Turkish banks' assets and liabilities before the onset of crises in 2001 .

\section{Figure 1.1: Marurity Structure of Turkish Banks' Assets} and Liabilities

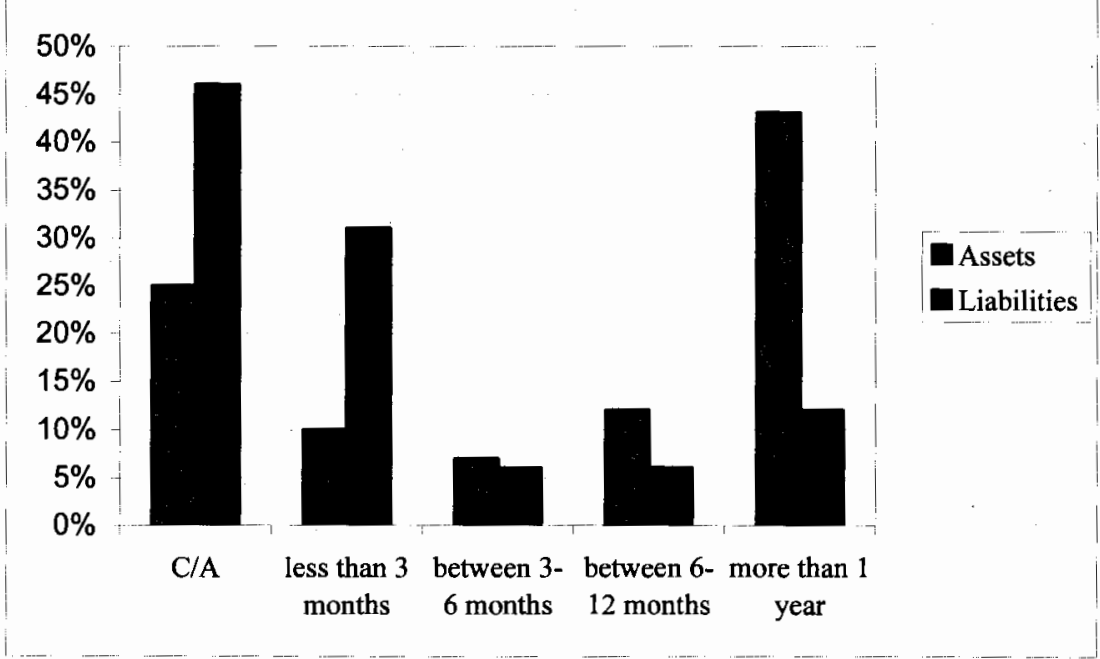

Source: Uygur, E. (2001),“Krizden Krize Turkiye: 2000 Kasim ve 2001 Subat Krizleri”, Ankara Universitesi Siyasal Bilgiler Fakultesi 
The banks in Turkey had huge long-term government bond portfolios funded by short-term liabilities and non-hedged open foreign currency positions. The interest rate rise to the four digit levels hit the mismatched $\mathrm{B} / \mathrm{Ss}$ and created funding losses as well as liquidity problems. The CMPs deteriorated due to changes in the yields. The open foreign exchange positions caused banks to make huge foreign exchange losses due to a sudden currency depreciation of almost $100 \%$, with the foreign exchange regime change from crawling peg to floating. The shrink in the economic activity caused banks to have serious problems also in their loan portfolios. The equities of the already under capitalized Turkish banking sector eroded. The macroeconomic shocks and their effect on the Banking System are illustrated in figure 1.2.

Figure 1.2: 2000-2001 Crises

\begin{tabular}{|l|l|}
\hline Macroeconomic Shocks & The Effects on the Banking Sector \\
\hline $\begin{array}{l}\text { Rapid and considerable increase in } \\
\text { Interest Rates }\end{array}$ & \begin{tabular}{l} 
Maturity Mismatch $\rightarrow$ funding loss \\
\hline Rapid depreciation of TL $\rightarrow$
\end{tabular}$\quad \begin{array}{l}\text { Considerable Value loss of the CMPs } \\
\text { Open Positions } \rightarrow \text { Exchange losses }\end{array}$ \\
\hline Slow-down in Economic Activity $\rightarrow$ & $\begin{array}{l}\text { Asset Quality } \\
\text { Credit Risk } \\
\text { Result: Capital Erosion }\end{array}$ \\
\hline
\end{tabular}

Source: Pazarbaşıŏlu, C. (2003), Conference hosted by BRSA on May 2003, www.bddk.org.tr. (access date Feb.2004)

Hence, the Turkish banking crises, which is similar to the systemic crises of some other developing countries, is different from the individual banking distresses in a number of EU member states where the predominance of microeconomic credit, market and operational risk exposures are observed. Credit, market and operational risks are not the major risk exposures of the banks in Turkey as there is crowding out and as derivatives are almost non-existent in Turkey. The major risk exposures of Turkish banks are interest rate and exchange rate risks.

\section{Risk Management Framework in the EU and Turkish Banking Systems}

The International Regulatory and Supervisory framework is designed by Bank for International Settlements (BIS) in order to minimize the risk of banking crises. The BCBS (Basel Committee for Bank Supervision) of BIS 
is set up by the Central Bank governors of G-10 (plus Luxemburg and Switzerland) in 1974 and plays a leading role in the international efforts towards supervisory cooperation and regulatory harmonization.

Basel Committee initiatives are enforceable in G-10. A closely parallel effort to harmonize the regulatory and supervisory framework is also observed in the EU. The EU initiatives are closely parallel to BCBS initiatives as nine EU Member States are represented in the Basel Committee and European Commission participates to Basel Committee meetings as observer. ${ }^{3}$ The EU legislation is designed to harmonize the standards between member states of the union and it is overlapping with the Basel Process. ${ }^{4}$ In the developing world, on the other hand, more than 100 countries- including Turkey- adopt the internationally harmonized standards.

\section{II.1. The Risk Exposure Spectrum of the Basel Frameworks}

In 1988, due to the complaints of unfair competition ad concerns regarding the financial health of international banks, BCBS leaded the development of a risk-based capital standard for the internationally active banks of G-10. The Accord has been phased in by 1993 and became a world standard in a short period of time.

\section{II.1.i. Basel I}

The Basel framework protects banks from risks by assigning capital charges for risk exposures. ${ }^{5}$ Basel I brought capital requirements to credit risk, as at the époque credit risk was considered as the main reason for banking crisis. However, financial innovation, the growth of derivative markets and derivatives disasters in the developed countries necessitated that the authorities amend the Accord in 1996 to take a better and separate account of market risk besides the credit risk. ${ }^{6}$ The risks incorporated in the Capital Adequacy Calculation of Basel I are demonstrated in table 2.1. 
Table 2.1: Capital Adequacy Calculation in Basel I

Total Capital

$$
\geq \quad 8 \%
$$

Credit Risk + Market Risk

The existing Basel I framework, , provides options for the calculation of capital adequacy to protect the banks against credit and market risks. The available options and risk weights are illustrated in tables 2.2 and 2.3

Table 2.2: Available Options for Calculation of Risks in Basel I

\begin{tabular}{|c|c|c|}
\hline Risk & Choice & Calculation Method \\
\hline Credit & No choice & Standard Approach \\
\hline Market & Simple & Standard Approach \\
\hline Market & Advanced & Internal Models Approach $(\mathrm{VaR})$ \\
\hline
\end{tabular}

Table 2.3: Basel Capital Adequacy Accord: Risk Weights

\begin{tabular}{|l|c|c|}
\hline \multicolumn{1}{|c|}{ Assets Included } & Risk Category & Risk Weight (percent) \\
\hline $\begin{array}{l}\text { Cash and loans to } \\
\text { Central Banks and } \\
\text { governments }\end{array}$ & 1 & 0 \\
\hline $\begin{array}{l}\text { Claims on public sector } \\
\text { entities }\end{array}$ & 2 & 10 \\
\hline Claims on OECD banks & 3 & 20 \\
\hline $\begin{array}{l}\text { Loans secured by } \\
\text { mortgages on residential } \\
\text { property }\end{array}$ & 4 & 50 \\
\hline $\begin{array}{l}\text { All other assets } \\
\text { including commercial } \\
\text { loans }\end{array}$ & 5 & 100 \\
\hline $\begin{array}{l}\text { Each off-balance sheet } \\
\text { item is scaled by a } \\
\text { conversion factor }\end{array}$ & 6 & Applicable weight \\
\hline
\end{tabular}

Source: Lindgren et al. (1996), Bank Soundness and Macroeconomic Policy, International Monetary Fund, Washington, D.C., pp.188-189 


\section{II.1.ii. Basel II}

The Basel Committee started communicating with the industry in 1999 for a new capital adequacy framework, due mainly to the discrepancies regarding the measurement of credit risk of the existing framework and the need for the inclusion of operational risk. BCBS assumes to finalize the "New Basel Capital Accord" (Basel II) by mid- 2004. Basel II, once finalized will replace the 1988 Basel CAA (Basel I) and is assumed to start being implemented by the G-10 at year-end 2006 and then adopted progressively by the developing countries like Turkey.

The New Basel Capital Accord proposal stands on three mutually reinforcing pillars. ${ }^{7}$ Pillar one covers on a consolidated basis, regulatory capital requirements for credit risk, market risk and operational risk. This first pillar is designed to improve capital adequacy regulation for credit risk, and to specify capital requirements for operational risk, while capital charges for market risk stay the same as in the Basel I framework. The other two pillars of the new Accord consist of Supervisory Review Process, in which interest rate risk is also handled, and Market Discipline. The risks incorporated in the Capital Adequacy Calculation of Basel II are demonstrated in table 2.4 .

Table 2.4:Capital Adequacy Calculation in Basel II

\begin{tabular}{|l|} 
Total Capital \\
\cline { 2 - 2 } Credit Risk + Market Risk + Operational Risk
\end{tabular}

Basel II, compared with Basel I's one-size-fits-all broad brush structure is more risk-sensitive, bases regulatory credit risk capital requirements relatively more in line with the economic capital, includes incentives for better risk management, and offers a flexible menu of approaches as shown in table 2.5 . 
Table 2.5: Available Options for Calculation of Risks in Basel II

\begin{tabular}{|c|c|c|c|}
\hline Choice & Credit Risk & Market Risk & $\begin{array}{c}\text { Operational } \\
\text { Risk }\end{array}$ \\
\hline Simple & Standardized Approach & $\begin{array}{c}\text { Standardized } \\
\text { Approach }\end{array}$ & Basic Indicator \\
\hline Intermediate & $\begin{array}{c}\text { Foundation Internal } \\
\text { Ratings Based Approach }\end{array}$ & & Standardized \\
\hline Advanced & $\begin{array}{c}\text { Advanced Internal Ratings } \\
\text { Based Approach }\end{array}$ & $\begin{array}{c}\text { Internal Models } \\
\text { Approach }\end{array}$ & $\begin{array}{c}\text { Internal } \\
\text { Measurement }\end{array}$ \\
\hline
\end{tabular}

The risk weights for credit risk in Basel II considerably changes. The privileges the OECD member countries like Turkey enjoy despite their low credit ratings are dismantled. Instead, sovereign, bank and firm risk weights are assigned according to the External Ratings as illustrated in table 2.6.

Table 2.6: Risk Weights Under the Standardized Approach

\begin{tabular}{|l|c|c|c|c|c|c|}
\hline Credit Rating & AAA to AA- & $\begin{array}{c}\text { A+ to } \\
\text { A- }\end{array}$ & $\begin{array}{c}\text { BBB+ to } \\
\text { BBB- }\end{array}$ & $\begin{array}{c}\text { BB+ to } \\
\text { B- }\end{array}$ & $\begin{array}{c}\text { Under } \\
\text { B- }\end{array}$ & Unrated \\
\hline Sovereign Risk weight & $0 \%$ & $20 \%$ & $50 \%$ & $100 \%$ & $150 \%$ & $100 \%$ \\
\hline Bank Risk weight & $20 \%$ & $50 \%$ & $50 \%$ & $100 \%$ & $150 \%$ & $50 \%$ \\
\hline $\begin{array}{l}\text { Bank risk weight to } \\
\text { Short-term claims }\end{array}$ & $20 \%$ & $20 \%$ & $20 \%$ & $50 \%$ & $150 \%$ & $20 \%$ \\
\hline
\end{tabular}

Source: Derived from BCBS, (2001) Consultative Document: The Standardized Approach to Credit Risk, S.D New Basel Capital Accord, www.bis.org/publ/bcbsca04.pdf, p. 8-12 (access date Febr.2004)

\section{II.2. The Comparison of Risk Management Regulation in the EU and the Turkish Banking Systems}

The 1988 Basel I framework that is amended in 1996 to incorporate market risk was a measure to provide capital adequacy for credit and also market risk due mainly to wide-spread use of derivatives in the developed world. The EU immediately initiated parallel directives. Turkey adopted the amended legislative framework in 2002 despite the almost non-existence of derivatives. The majority of banks in Turkey are now using the Standard Method (SM) of the Amended Basel I framework, which requires almost no capital charges for the CMPs of Turkish Banks. However, one of the major 
reasons behind the 2000-2001 crises was the huge CMPs of the Turkish Banks, which were funded with the mismatched short foreign exchange positions and short-term borrowing. Turkey will adopt the Basel II framework, which will further increase the capital requirements of banks but will not offer protection to the true risk exposures of Turkish banks.

The banking legislation in the EU and the corresponding Turkish law and regulations for Risk Management stem from the same BIS framework. ${ }^{8}$ The Banking Law No: 4389 dated 19 December 1999 in Turkey is in many areas parallel to the EU legislative framework for banking. ${ }^{9}$ However, there are certain BIS principles that have not turned into parallel legislations in the EU either because they are incorporated in the Basel framework or because they are to the interest of developing countries. ${ }^{10}$ The crucial point here is that some of the BIS principles that interest the developing countries like the "Core Principles for Effective Supervision", designed after the Asian crises, is not adopted by EU and hence by Turkey. ${ }^{11}$ Also "Principles for the Management of Interest Rate Risk" which has a crucial importance for developing countries like Turkey due to the high volatility in interest and exchange rates is not adopted by EU and hence by Turkey. ${ }^{12}$

The existing wide differences in terms of risks between the EU and Turkey and quite converged regulatory frameworks to cope with these risks, mostly through precise adoptions is one of the main reasons behind the banking problems in Turkey. The Basel framework increases the requirement for capital adequacy in Turkey but does not offer protection to the risks the banks in Turkey are exposed. The harmonization of banking regulations of Turkey with the EU is important but the immunization of the system from crises will only be achieved with the adaptation of the framework to Turkey, rather than precise adoption of the best practices.

\section{The Problems Encountered and to be Encountered with the Implementation of Basel Risk Management Frameworks in Turkey}

Turkey encounters problems with the application of Basel I and seems will encounter new problems with the implementation of Basel II. These problems are due to precise adoption of the Basel frameworks. 


\section{III.1. The Problems Encountered in the Application of Basel I}

The Basel I framework covers the individual bank failure risks of the developed countries by assigning capital charges to credit, market and operational risks. The institutional risks and the macroeconomic shocks that cause systemic banking crises in Turkey are all ignored.

Turkey precisely adopts the risk weights for credit risk of Basel I. However, especially the $0 \%$ risk weight to government borrowing is not appropriate for Turkey due to the risks associated with the CMPs in the $\mathrm{B} / \mathrm{Ss}$ of banks.

The differences between the risks the EU and TBS are exposed and the extent of macroeconomic volatility in Turkey justify that the worldwide $8 \%$ Minimum Capital Requirement (MCR) is not enough to absorb the risks in the TBS. Turkish Banks need to be better capitalized as they are exposed to serious volatilities in interest and exchange rates. Hence, in Turkey the discretionary power of the authorities should be better exercised in taking the country and institution specific factors into account when issuing regulations.

Basel I apply to only banks but not to other financial institutions. However, for Turkey, the increase in the transparency and standardization of the accounting standards and the strengthening of all the financial institutions is vitally important.

There is no need for the regulatory framework in Turkey to explain in full length the measurement of Options positions risks or for complex derivative risks since derivatives are almost non-existent in the Turkish financial markets. ${ }^{13}$

In Turkey, a risk management culture that uses the risk sensitivity in the decision-making processes of both the Asset / Liability Committee members and Treasury Managers could not be established. This is mainly due to the following factors: SM of Basel I is used by the majority of banks and the use of SM does not allow for evaluation of risks in the decision making process. The main reason for the widespread use of SM is the cost of the 
Internal Risk Management Models and the low Capital Adequacy Ratio achieved with the use of SM. ${ }^{14}$

The Duration Gap Analysis used in the SM to measure the interest rate risk is not appropriate for Turkey due to the risk weights of the time bands. The maturities up to 1 month receive a $0 \%$ risk weight. However, the maturities of especially the deposits and repos are very short termed in Turkey. The SM for Market Risk assigns $0 \%$ risk weight to specific interest rate risk of government bonds hence does not properly measure even the risk of trading CMPs. The SM for market risk also ignores volatilities. However, the main economic risk for Turkey is the' extent of macroeconomic volatility in interest and exchange rates. Thus, the SM applications that are widely used in Turkey do not play a role of immunizing banks from probable new systemic risks.

The Internal Models Based Approach (IMBA), which uses the Value at Risk (VaR) methods for the computation of market risk, measures VaR of only the trading portfolios. The risk weight of the investment CMP is considered as $0 \%$ under the existing Basel I framework. However, this is not a valid approach for Turkey since the main risk arises from the huge government deficit and the consequent huge government borrowing.

As Sezgin points out, there are deficiencies in the use of VaR methods in Turkey. ${ }^{15}$ In the parametric VaR computations, due to the distribution normality assumption, the effects of the huge volatilities in the exchange and interest rates are not properly reflected. The determination of the yield curves is problematic due to the illiquidity and the shallowness of the markets. ${ }^{16}$ The frequency and extent of volatilities in Turkey also cause problems in the volatility forecasting methods. ${ }^{17}$ The differences in the liquidity of instruments in the CMP and the continuous change of liquid instruments in the portfolio due to the shortness of maturities necessitates continuous instrument wise arrangements in the $\mathrm{VaR}$ calculations of Turkey. Also, there is the crude aggregation of the credit and market risks in the SM and the IMBA and the Turkish markets are exposed to an aggregation risk due to the fact that risks are not normally distributed. 
The Value at Risk (VaR) computations also verifies that there are extreme differences between various VaR methods. ${ }^{18}$ Actually, the use of $\mathrm{VaR}$ is more of an art than science and VaR methods are useless if the operating environment and the management incentives are deficient as the case is in Turkey. Also, for Turkey, system wise stress tests are needed rather than stress tests applied by individual banks due to the systemic nature of crises in Turkey.

\section{III.2. The Possible Problems to be Encountered with the Application of Basel II}

The Standard Approach of Basel II necessitates sovereign, bank and firm credit ratings from Export Credit Agencies (ECAs) and / or External Credit Assessment Institutions (ECAIs) However, ECA and ECAIS and the rating concept are almost non-existent in Turkey, despite the fact that Turkey will be applying the simplest of the methods, the Standard Method rather than Internal Ratings Based Approach (IRBA). The necessity to have external rating will force firms in Turkey to have a rapid external rating and possibly the development of some deeper relations with the rating agencies.

There will be problems due to increase in MCR that will induce a very sharp cost increase and reduction of loans to developing countries like Turkey. As Jones and Spratt emphasize, the playing field cannot be levelled if for a B- rated company, the capital requirement rises from $8 \%$ to $20.8 \%$, whereas for an AA- borrower in the developed world, the capital requirement ${ }^{\prime}$ drops from $8 \%$ to $1.18 \%$. ${ }^{19}$

There will be an increased risk of developing world crises in consequence of increase in costs and reduction in lending to developing world and the widespread use of IRBA application that may increase procyclicality of lending to developing countries.

There will most probably be a consolidation problem for banks in the developing countries due to the comparative capital requirement advantage of the already strong IRBA banks.

In terms of risk weights, the $100 \%$ risk weight assigned by the SM to non-rated corporate claims will create a positive disincentive for those afraid of being rated below B- in Turkey. As $0 \%$ risk weight is assigned to 
lending in domestic currency to Treasury or State-owned enterprises, the risk of the non-trading CMPs will still not be incorporated into the risk measurements. As pointed out by Özcan, the introduction of $100 \%$ risk weight for lending in other currencies to Treasury or State-owned enterprises, on the other hand, will cause problems in terms of securitization and syndication and also will increase the cost of international banks' lending to Turkey. ${ }^{20}$ Also, while reduced, the low risk weights assigned for banks' short term borrowing is problematic since short-term borrowing creates problems in countries like Turkey due to the sudden reversals of inflows.

In terms of Risk Mitigating Techniques, post-dated checks assigned to banks and promissory notes that are widely used as collateral in Turkey are not recognized as risk mitigants in the Basel II framework, despite the fact that they are drawn due to a trade transaction. ${ }^{21}$

The IRBA of Basel II requires from the banks a credit risk rating system with the data set for their credits. ${ }^{22}$ At minimum 5 years of historical Probability of Default (PD) data is needed for the Foundation IRB, 7 years of Loss Given Default (LGD) and Exposure at Default (EAD) will be necessary to move to Advance IRB. This will create problems for Turkish banks, as most of them are even unaware that the rules of the game for banking are changing. Also, it is hard to collect trustable past data in Turkey about the credits and defaults due to lack of transparency, the nonestablished international accounting standards and unofficial economy that are quite common. The high default rates and high volatility in economic activity in emerging markets, even with the foundation IRB based capital requirements are hard to verify and calibrate, thus are discouraging. Hence, as suggested by Aksel for developing countries like Turkey some parameters need to be changed. ${ }^{23}$

The IRBA is designed to move away from exter anal regulation and towards market discipline. However, the complexity of IRBA, the data set and system-wise problems, the very high compliance costs, lack of skills and expertise even for EU member states makes it almost impossible for Turkish banks to move soon to the foundation IRBA. For the top 100 banks, it could take from 2 to 5 years, cost up to $\$ 40$ million, and extra staffing of 
20-75 personnel to develop and build a fully integrated credit risk management system. ${ }^{24}$

In the IRBA, the capital requirements that are determined by PDs have a cyclical nature. PD is relatively low during booms causing a reduction in regulatory capital. The MCR will increase during periods of recession and this cyclic effect will be more pronounced for Turkey due to the extent of volatility. ${ }^{25}$

For Operational Risk, it is hard to measure and collect data for operational risk and returns are not normally distributed in Turkey and these will create misleading VaR results. Banks in Turkey will be using the Basic Indicator Approach for operational risk. This means that Turkish banks will need $15 \%$ of capital for operational risks. ${ }^{26}$

The Basel framework is designed for developed countries, not for the developing world. The practice of precise adoption of the Basel rules by the developing countries like Turkey will not immunize the banking systems from new banking crises.

\section{The Proposals to Increase the Efficiency of Risk Management in Turkey}

The systemic banking crises that continue with an increased frequency in countries like Turkey can only be prevented with the coordinated efforts of the Basel Committee, the regulatory and supervisory authorities and the banks.

\section{1. In the framework of the Basel Committee Initiatives:}

The Basel Committee initiatives target to bring financial stability and to level play the field. Basel Committee should however be aware of the fact that the international financial stability will not be achieved with the increasing financial instability in the developing countries. To that end, Basel Committee has certain responsibilities:

Basel Committee should take into consideration the different macroeconomic, microeconomic and institutional risks of the developing world in its international efforts to bring financial stability. Also, Basel Committee should not draw initiatives that will deepen the already existing 
gap between the developing and developed world since the aim of the Basel Committee is in the mean time to level the playing field.

\section{2. In the framework of Responsibilities of the Regulatory' Supervisory Authority:}

Until the Basel II framework, Banking Regulation and Supervision Agency of Turkey (BRSA) should redefine the Risk Management Regulation in Turkey by taking into consideration the country specific problems that Turkey encounters in the application of Basel I; and immediately start implementing the 1997 "Principles for Interest Rate Risk Management". ${ }^{27}$

Concerning Basel II, BRSA should inform the government about the fact that the rules of the game will be radically changing by end-2006 and force the government to lobby for their problems during the very limited time left. ${ }^{28}$ BRSA should also invite the shareholders of banks to the established Steering Committee for Basel II, and cooperate with the Regulatory/ Supervisory Authorities of the other developing countries.

For the moment, Turkish firms, banks and existing rating agencies are doing almost nothing for the Basel II process. However, Basel II will have serious affects on Turkey whether the new framework is adopted / adapted or not. Moody's and S\&P have started ratings in Pakistan and India. Firms in Spain, Germany, France, Switzerland, Italy and Poland are rushing for external rating. Germany and Australia have their own rating agencies since international rating agencies do not rate Small and Medium Sized Enterprises (SMEs) even in the EU. Turkey must also have domestic rating agencies for SMEs. The Turkish firms should start to have external ratings. For the IRB Foundation Approach, the banks should start PD data collection. Hence BRSA should lead the industry about what banks, firms and rating agencies should do.

BRSA should be in close cooperation with banks and design the regulatory framework using the discretionary power where possible in order to prevent the possible problems to be encountered in the application and in order for the regulatory framework to offer protection to the true risk 
exposures of Turkish banks, instead of copying regulations as the case was with Basel I.

\section{IV.3. In the framework of the Responsibilities of Banks:}

Basel II framework underlines that it is the bank's responsibility to properly measure and manage their risks. The problems so far evaluated in terms of the risks and risk measurement methods necessitate that the banks in the developing countries find, within the broad legislative framework, their own solutions for the management of their own risks. Hence, even if BRSA does not change the Basel I rules for Risk Management, the banks should apply higher standards than BRSA requires. Also, even if BRSA does not start implementing the "Principles for Interest Rate Risk Management", the banks should start implementing the Asset Liability Management (ALM) Techniques, besides getting prepared for Basel II. ALM is vital for banks in countries like Turkey as it offers the means to measure and control the major risk exposures of banks, the interest and exchange rate risks.

The need for ALM arises due to two important problems in the TBS. The first reason is that the main source of profit due to the high indebtedness of the government becomes the main source of problem during crises because of the extent of macroeconomic volatility in interest rates and foreign exchange rates. In Turkey, the other most important problem is the non- established risk management culture. In the TBS, "Passive" risk management is applied and the efforts are to move to "Defensive" risk management in order to control risk. However, "Active" risk management should be the policy. ${ }^{29}$ The coordination between the risk department and the treasury department in banks is vitally important for the management of risk on time. The risk management culture with the daily market risk computations, with foreign exchange rate and interest rate shocks applied, with limits set and observed according to risk, with VaR models backed by stress tests and scenario analysis and with the performance evaluations that takes risk levels into account should be established.

Neither Basel I, nor the Basel II framework that Turkey intends to adopt provides concrete solutions for the Asset / Liability Management of banks. SM of Basel I uses the Duration Gap Analysis for the calculation of interest rate risk. However, it is a reporting based analysis and cannot provide active 
risk management. On the other hand, the VaR models cannot calculate the ALM risk. The VaR due to interest rate risk, the effect of maturity mismatch on the profit/ loss and economic value, the required capital to get protected against interest rate risk cannot be computed with the VaR methods that are used in the existing framework. In the Supervisory Review Pillar II of Basel II, it is underlined that supervisors can require a reduction in risk or an increase in capital especially for banks whose interest rate risk leads to an economic value decline of more than $20 \%$ of Tier $I$ and Tier 2 capital due to a standardized (2\%) interest rate shock. However, a standardized $2 \%$ interest rate shock is quite inadequate for the interest rate risk measurement of Turkey where the $\mathrm{O} / \mathrm{N}$ Interbank rates may rise up to $7000 \%$ as the case has been during the 2001 crises.

For ALM, BIS set Principles for the Management of Interest Rate Risk in 1997. The Sources of Interest Rate Risk that have to be measured are specified as Reprising Risk, Yield Curve Risk, Basis Risk and Optionality Risk. The Effects of Interest Rate Risk are defined as Income Effect and Value Effect. Value Effect measures sensitivity of a bank's economic value to interest rate fluctuations by Duration, Sensitivities and Value at Risk. Income Effect measures the sensitivity of a bank's earnings to fluctuations in interest rates by Gap Analysis, Dynamic Income Simulation and Earnings at Risk. Hence, Gap Analysis, Duration Analysis and Static-Dynamic Sensitivity Analysis are indicated as options to measure interest rate risk. The BCBS published a revised version of 1997 principles in 2003 with the aim of detailing the risk management principles of the Basel II. $^{30}$ It is underlined in the (Consultative Document) CP that banks should have a risk management process that effectively identifies; measures, monitors and controls interest rate risk exposures. The interest rate risk of the trading portfolios are to be measured with VaR and of non-trading portfolios with Gap Analysis, Duration Analysis or Static-Dynamic Sensitivity Analysis. The changes between the 1997 and 2003 principles for interest rate risk management are in Principle 13-15 and in Annexes 3 and 4. ${ }^{31}$ The major difference between 1997 and 2003 principles is detailed in Annex 3. ${ }^{32}$

For Turkey, under the Basel II framework, Duration Gap Analysis and Static Sensitivity Analysis should be made compulsory instead of providing options of Gap Analysis or Duration Analysis or Static- Dynamic 
Sensitivity Analysis. These two methodologies would be more commensurate with the complexity of Basel II and will hinder Turkish banks from applying the least costly but least protective ALM technique of Gap Analysis. However, these new principles for interest risk measurement will be effective by earliest 2007 for Turkey. Hence, Turkish banks should adapt the 1997 "Principles for Interest Rate Risk Measurement" without losing anymore time. Amended Basel I allows banks to apply a Combination of Internal Models and SM. Hence, an Automated Combination of the SM should be used with the VaR methodology in order to incorporate the effects of interest rate risk measurement. The Combined Methodology should use the Duration Gap Analysis and Sensitivity Analysis for the measurement but particularly on line management of interest rate risk.

\section{Conclusions}

The Basel framework is designed by the developed world and for the developed world. The practice of precise adoption of the Basel rules by the developing countries like Turkey will not immunize their banking systems from new banking crises. Turkey adopted Basel I and will adopt Basel II framework in line with the efforts to harmonize the banking regulations of Turkey with the EU. However, with the adoption of Basel frameworks, banks in Turkey will not be protected against their major risk exposures. The systemic banking crises that continue with an increased frequency in the developing world can only be prevented with the coordinated efforts of the Basel Committee, the regulatory and supervisory authorities and the banks in the developing world. Consequently, Basel Committee should be aware of the fact that international financial stability will not be achieved with the increasing financial instability in the developing world. The Regulatory and Supervisory Authorities in the developing countries like Turkey should be in close cooperation with banks and design the regulatory framework using the discretionary power where possible, instead of copying regulations. Last but not least, since it is the banks' responsibility to measure and manage their risks, banks should apply higher standards than BRSA requires and start implementing Asset Liability Management Techniques in order to manage their interest and exchange rate risks, which are the major risk exposures of banks in Turkey. 


\section{Endnotes}

${ }^{1}$ Gonzalez- Hermosillo researched in 1999 early warning indicators of individual bank failures across countries by using a regression model, employing bank specific indicators together with institutional factors like moral hazard, and also macroeconomic, regional, contagion factors. Their study suggests that individual bank failures are strongly associated with liquidity, market, credit risk and the macroeconomic environment. Their conclusion is that the primary warning signals are the non-performing loans and equity capital ratios and that the leading indicators of individual banking crises show inconsistencies across countries as country cases exhibit idiosyncratic characteristics. (For more details see Bell, J., 2000, "Leading Indicator Models of Banking Crises - a critical review by James Bell", pp.5- 6 Financial Stability Review- December 2000), Demirgüç-Kunt and Detragiache (1997) studied the determinants of systemic banking crises for a sample of 30 developed and developing market economies for the period of 19811994. The findings of the study discloses that low GDP growth, high real interest rates, inflation, and the ratio of $\mathrm{M} 2$ to reserves which is a measure of external vulnerability is significantly related to the probability of systemic banking crises. In terms of institutional determinants, high values of "law and order" and the existence of explicit deposit insurance are found to be strongly correlated with systemic banking crises and these two indicators are more significant when the sample is restricted to developing countries. (For more details see Demirguc- Kunt and Detragiache E. (1997). "The Determinants of Banking Crises: Evidence from Developing and Developed Countries", IMF Working Papers 106)

${ }^{2}$ Gup, B. (1998), "Bank Failures in the Major Trading Countries of the World: Causes and Remedies", Quorum Books, London

${ }^{3}$ The EU countries that are represented in the Basel Committee are namely Belgium, France, Germany, Italy, Luxembourg, the Netherlands, Spain, Sweden and the United Kingdom

${ }^{4}$ The Basel Committee initiatives, after negotiations and modifications, become EU Directives and are adapted by the EU member states.

${ }^{5}$ The adequacy of capital is important as it serves as a cushion against a fall in the value of bank's assets and losses, absorbs future unidentified losses, and provides incentive to refrain from excessive risk taking. Capital also plays a critical role on 
the soundness and governance of banks and also can be a measure defining the threshold for the transfer of control to the regulators.

${ }^{6}$ BCBS. (1996). "Amendment to the Capital Accord to Incorporate Market Risks", Basel

${ }^{7}$ For Basel II the reader is recommended to refer to the following BIS and BCBS documents

BIS. (2001). "Overview of the New Basel Capital Accord", Basel, www.bis.org/publ/bcbsca02.pdf

BIS. (2001). "The New Basel Capital Accord: an explanatory note", Basel www.bis.org/publ/bcbsca01.pdf

BCBS. (2003). "Consultative Document, Overview of the Basel Capital Accord", Basel (access date Febr. 2004)

${ }^{8}$ The related BIS principles behind the legal structure of the EU and adopted legal structure of Turkey particularly for the management of risk are the Principles of International Convergence of Capital Measures and Capital Standards and the related Amendments; Measuring and Controlling Large Credit Exposures and IntraGroup Transactions and Exposures and Risk Concentration Principles; International Accounting Principles; Framework for the Evaluation of Internal Control Systems; Sound Practices for Loan Accounting; Credit Risk Disclosure and Related Matters; Enhancing Bank Transparency; Internal Audit in Banking Organizations and the relationship of the Supervisory Authorities with Internal and External Auditors and Enhancing Corporate Governance in Banking Organizations

${ }^{9}$ See www.tbb.org.tr for Turkish, www.bis.org for BIS and www.europa.eu.int for EU legislation on Banking. (access date Febr. 2004)

${ }^{10}$ The BIS principles that do not have corresponding EU directives are:

a) The management of banks' international lending: country risk analysis and country exposure measurement and control

b) The management of banks' off-balance sheet exposures: a supervisory perspective

c) Framework for supervisory information about the derivatives activities of banks and securities firms

d) Principles for the Management of Interest Rate Risk

e) Core Principles for Effective Banking Supervision

f) Operational Risk Management

g) Sound Practices for managing liquidity in Banking Organizations 
h) Supervisory Guidance for Managing Settlement Risk in Foreign Exchange Transactions

i) Principles for the Management of Credit Risk

j) Sound Practices for Banks' Interactions with Highly Leveraged Institutions

k) Customer due diligence for Banks

1) Supervisory Guidance on Dealing with Weak Banks

m) Parallel-owned banking structures

n) Shell banks and banking offices

o) Consolidated KYC Risk Management

${ }^{11}$ BCBS. (1997). Core Principles for Effective Banking Supervision, Basel www.bis.org/publ/bcbs30a.pdf (access date Febr.2004)

${ }^{12}$ BCBS. (2003). “The Principles for the Management of Interest Rate Risk”, Basel, www.bis.org

${ }^{13}$ The trading portfolios are quite small and the trading activity is much less in countries like Turkey when compared with the developed countries like the EU member states. The commercial banks do not trade equities for their customers, there is almost no bank that writes options, the interest rate and money futures and swaps are at negligible levels. Foreign Exchange (FX) and CMP risks are the major sources of risk for Turkey.

14 The results of VaR computations even with the Variance- Covariance method produced twice as high $\mathrm{VaR}$ and MCR results compared to the results of the Standardised Approach.

${ }^{15}$ Sezgin, C.,(2002). "Risk Yönetimi Uygulamasında Yaşanan Sorunlar”, pp.7-13 Conference held at İstanbul Trade University on March 5th 2002

${ }^{16}$ In the Turkish financial markets, there is a concentration of maturities in short term, the shallowness of markets decreases the indicative nature of the mediumterm instruments' interest rates on the yield curve and the instruments with long term maturities are illiquid.

${ }^{17}$ Sezgin (2002) assert that the TL interest rate volatility for 91 days is estimated as $1.6 \%$ with EWMA 0.94 and 6,75\% with Simple Moving Average. 
${ }^{18}$ The reader can refer to the unpublished thesis of the author for the results of VaR computations for the Turkish Banking System.

19 Jones, G.and Spratt S.(2003), « CP 3 Comments», www.bis.org/bcbs/cp3 comments.htm (access date Dec. 2003)

${ }^{20}$ Özcan, H., (2003) "Basel II is a Chance", unpublished notes from the TIDE meeting held at Garanti Bank, pp.5.

${ }^{21}$ This problem, and some others have been conveyed by BRSA to BIS as a response to the latest Consultative Document, (CP3).

${ }^{22}$ The foundation IRBA requires the computations of Probability of Default (PD) with the banks' risk rating system based on bank's own estimates. The Advanced IRBA requires the bank to compute PD, Loss Given Default (LGD), Exposure at Default (EAD) and Maturity (M) with the risk rating system based on bank's own estimates.

${ }^{23}$ Aksel, K. (2003). "Basel II is a Chance", unpublished notes from the TIDE meeting held at Garanti Bank, pp.12.

${ }^{24}$ Insero, R. (2002). "Credit Risk Data Challenges Underlying the New Basel Capital Accord", the RMA Journal April 2002

${ }^{25}$ During crises, the low PDs will require additional capital. However crisis periods are not the best times to raise private capital, which may consequently cause a credit crunch and deteriorate the financial problems.

${ }^{26}$ The developed countries will compensate this increase in MCR with the decrease of capital requirements they will enjoy due to the use of IRBA and this will not be the case for Turkey.

\section{${ }^{27}$ BCBS(1997) Principles for Interest Rate Risk Management}

${ }^{28}$ The blockage of USA for Basel II has already postponed the finalisation of Basel process to mid-2004. One single developing country might not produce a similar affect but tens of developing country governments exerting pressure may produce similar results. Also, lobbying today is better than opting out like China and India have already done and like many others more will most probably do. 
${ }^{29}$ Evolution in Applications of VaR

A) Passive

\begin{tabular}{|l|}
\hline Reporting Risk \\
\hline Disclosure to Shareholders \\
\hline Management Reports \\
\hline Regulatory Requirements \\
\hline
\end{tabular}

B) Defensive

\begin{tabular}{|l|}
\hline Controlling Risk \\
\hline Setting Risk Limits \\
\hline (desk level and firm-wide) \\
\hline
\end{tabular}

C) Active

\begin{tabular}{|l|}
\hline Allocating Risk \\
\hline Performance Evaluation \\
\hline Capital Allocation \\
\hline Strategic Business Decisions \\
\hline
\end{tabular}

Source: Jorion, P. (2000). "Value at Risk", Conference Notes from the Conference organized by WB and TBB held in Istanbul

${ }^{30}$ BCBS. (2003). "The Principles for the Management of Interest Rate Risk", Basel, www.bis.org

${ }^{31}$ Principle 13 is about interest rate risk public disclosure. Principle 14 is about standardised interest rate shock results of banks to be submitted to the supervisory authority for supervisory treatment. Principle 15 is about immediate remedial action of supervisors to increase the capital or reduce the risk or a combination of both. In Annex 4 an example of a Standardised framework for Gap Analysis is supplied

${ }^{32}$ In Annex 3, the framework is described as also allowing institutions to use these parameters for calculating appropriate shocks themselves when they have material exposure outside G-10 countries and for supervisors in emerging market and other 
non-G-10 countries to derive simple shocks that are appropriate for their own countries. In Annex 3 it is also mentioned that the relative simplicity of a $200 \mathrm{bp}$ parallel rate shock has the disadvantage of ignoring exposures that might be revealed through scenarios that include yield curve twists, inversions and other relevant scenarios. Supervisors will continue to expect institutions to perform multiple scenarios in evaluation of their interest rate risk as appropriate to the level and nature of risk they are undertaking. 